\title{
Uma história da difusão das Escrituras Sagradas: a atuação das Sociedade Bíblicas no Brasil
}

\author{
Orientador: Luís Corrêa Lima \\ Doutoranda: Acyr de Gerone Junior \\ Área de Concentração: Teologia Sistemático-Pastoral \\ Linha de Pesquisa: Religião e Modernidade \\ Projeto de Pesquisa: História da Igreja e Modernidade: Permanências e Mu- \\ danças
}

Esta tese foi desenvolvida com o objetivo de analisar a história da difusão das Sagradas Escrituras por meio da atuação das Sociedades Bíblicas no Brasil. Para melhor contextualizar a temática, a caminhada teve início no tempo da transmissão oral da Palavra de Deus, antes de qualquer registro por escrito, e se desenvolveu pelos diversos contextos em que as Escrituras acompanharam o povo de Deus na história, tanto na realidade do povo de Israel quanto na perspectiva da igreja cristã. O trabalho de difusão das Escrituras, realizado pelas Sociedades Bíblicas no Brasil, constituiu o objeto principal do estudo. Analisou-se como se deu o processo de chegada e o desenvolvimento do trabalho das Sociedades Bíblicas em quase duzentos anos de atividades no país. De forma especifica, discorreu-se sobre o trabalho realizado pela Sociedade Bíblica do Brasil (SBB) desde a sua fundação, em 1948. Esse trabalho foi analisado a partir do clico de vida da Bíblia, método utilizado para a SBB tornar a Bíblia disponível, acessível e relevante na sociedade e na igreja. O trabalho foi desenvolvido sob as bases de uma pesquisa histórica. Sua área de concentração foi estabelecida na teologia sistemática-pastoral. O objeto material foi a análise da caminhada histórica do trabalho de difusão das Escrituras Sagradas realizado pelas Sociedades Bíblicas no Brasil, especialmente a SBB. O objeto formal foi desenvolvido com as contribuições de Luiz Antonio Giraldi. Metodologicamente, a pesquisa foi realizada por meio de uma revisão bibliográfica, contemplada por historiadores e biblistas que são refe- 
renciais em relação a temática proposta. Foram também utilizadas pesquisas em documentos oficiais disponibilizados pela SBB. No último capítulo foram utilizados além da descrição histórica, uma análise de conteúdo com base nas atividades desenvolvidas pela SBB por meio do ciclo de vida da Bíblia. Os resultados evidenciaram que o trabalho de difusão das Escrituras, desenvolvido pelas Sociedades Bíblicas no Brasil, em especial a SBB, tem contribuído de forma significativa com a igreja e a realidade da sociedade brasileira em diversos aspectos.

Palavras-chave: Sociedade Bíblica do Brasil. Bíblia. Teologia. 